\title{
WHITMAN'S IDENTITY AT WAR: CONTEXTS AND RECEPTION OF JOHN ADAMS'THE WOUND-DRESSER
}

\author{
Heidi Kathleen Kim
}

"This Is our American war-song, good not only for the battle-field, but for the labor-field - the present, still more than the past; for ours are not the 'piping times of peace;' our American life is on the march, filing through the passes of outgrown formalism, outflanking the hosts of slavery, gaining the mountain heights of an all-comprehending vision," wrote an anonymous critic of Drum-Taps in $1865 .{ }^{1}$ He was already willing to apply Walt Whitman's war-song to the present rather than the recent past, using it as inspiration for life on the metaphorical march rather than a literal war. Such is also the case in modern times with John Adams' famous song-setting of "The Wound-Dresser" from Drum-Taps. Since its premiere in 1989, The Wound-Dresser has evoked contradictory interpretations about its relevance that reveal how the debates over Whitman's identity continue to seethe in the public sphere.

In "The Wound-Dresser," initially entitled "The Dresser," an old man addresses young listeners asking about a war long past. Whitman's narrator offers a reminiscence not of a righteous North, nor of heroic battles and death and glory charges, but of a war in which one side was as brave as the other; the lingering memories are of his care of the desperately wounded. He describes the Civil War not in grand terms, with reference to famous figures, but in the suffering of anonymous individual soldiers. His care and compassion create a special bond between him and these young men, one perhaps impossible without the intimacy forced upon them by the exigencies of war. Or, as Adams put it to New York Philharmonic conductor Alan Gilbert, "It's Whitman ... there's gotta be a little sex in here, not all suffering and dying."”

These poles of Whitman's identity might be easily brought together in Adams' dry aside, but less so in public discussion. As Betsy Erkkila writes, the "fairly standard divisions in Whitman studies - the aesthetic Whitman, the sexual Whitman, the historic Whitman, the political Whitman- . . tend to mask the complexly interactive social, sexual, and historical engagements of Whitman's work." Rather than using the historic and political Whitman to legitimize the sexual Whitman, 
Erkkila calls for a new consideration of his "multiple and often contradictory bequests to the future." 3 As "The Wound-Dresser" became The Wound-Dresser and moved into the world of classical music, the discussion of Whitman's identities collided with Adams' authority and the delicate topic of modern warfare of various kinds. These issues all create a constantly shifting reception in which the traces of Whitman's disparate public identities can be seen more clearly, perhaps, than in scholarly Whitman studies.

The dominance of debate about Whitman's original intentions and opinions shows how strongly his authorial authority endures, but it also reveals the uncertain nature of Whitman's multitudinous identity. If, as Lawrence Buell summarizes, we continue in the well-established scholarly theory that the "war enabled Whitman to redefine his persona from the brash unwashed omnisexual cosmic-anarchic force to the compassionate, maternal nurturer and patriotic chronicler of historic events," "then we must also recognize how strongly that patriotic persona overwhelms the perceptions of a general audience, who we may reasonably assume were first taught selected poems from Drum-Taps (such as "O Captain! My Captain!") and perhaps were later introduced to a separate sexual Whitman. Musicological studies of The WoundDresser do not bridge the gap, usually focusing, as the field demands, on Adams' intriguing musical structures. For this reason, I turn to the program notes and newspaper and magazine reviews of performances and recordings, as well as some noted performers, to narrativize the discussions that arise from a modern public understanding of Whitman and his discontents.

Adams' composition was commissioned by Carillon Importers on behalf of Absolut Vodka and the Saint Paul Chamber Orchestra. The orchestra premiered it in February 1989 with Canadian baritone Sanford Sylvan, a frequent Adams interpreter, and Adams himself conducted. The piece is scored for a baritone and a small chamber orchestra: strings, winds, horns, a synthesizer (one of Adams' favored modernizations), and timpani. Adams cut the opening address of the old narrator to his audience, making it a more present, vital reminiscence in keeping with song traditions, and also bringing the song to a close at a reasonable nineteen minutes. It starts with the lines, "Bearing the bandages, water and sponge, / Straight and swift to my wounded I go," and proceeds through the rest of the poem, punctuated by mournful trumpets reminiscent of the battlefield.

The Wound-Dresser has had a recent surge of performances, motivated partly by the American interest in English-language song and opera that has also led to a resurgence of composers such as Benjamin Britten. The song has been well received since its first performance, though with an extraordinary range of adjectives; it has been called 
gloomy, triumphant, compassionate, refined, understated, overpowering, gravely beautiful, and restless. Written in what one reviewer dubbed Adams' "most accessible manner, combining a recitative-like presentation of the text with richly traditional triadic harmonies," the song certainly falls into his "dark, introspective, 'serious" oeuvre. Another calls it "one of the slowest, most pensive compositions in the Adams canon," introducing the clash of Adams' canon and Whitman's. ${ }^{5}$

The presidentially named John Coolidge Adams is one of the foremost American classical composers of the last fifty years, with strong roots in minimalism. The rich harmonies of The Wound-Dresser depart from Adams' youthful minimalist identity, and its slightly more traditional nature perhaps accounts for its broad appeal. Still, musical opinion was divided (or occasionally even negative) about the piece's merits. Critic Gerald Fox wrote, "I have always thought the orchestral music more gripping than the vocal line, which is weak melodically," whereas his counterpart at Gramophone opined, "The baritone's melodic line, bluntly literal in its adherence to speech patterns, at times seems out of place against the frank sentimentality of the background music, redolent of the Hollywood movie-score." In addition to these divided opinions about the vocal melody (noting the emphasis on melody as a positive attribute), performance critiques have also noted the occasional domination of the vocalist by the orchestra. ${ }^{6}$

Adams, who is an extraordinarily thoughtful and eloquent writer as well as composer, emphasized Whitman's Civil War experiences in his original published notes about the song, dated 1988. He offers a portrait of Whitman nursing the "tens of thousands of sick and maimed soldiers" dying "slow, grievous deaths, feverish, hallucinating, without pain-killing drugs." Adams' interviews have offered the other interpretation that critics have happily seized upon - that his father's death from Alzheimer's and the four years of patient nursing that his mother endured influenced his writing. This biographical angle came from an interview with Adams published before the piece even premiered. He said, "Somehow, I had gone through a personal thing where my father had died of a very long, slow, illness. My mother had nursed him through the last four years up until the time he died. And ironically, he died during the writing of this piece. I'm not even sure it's a good piece. I finished it. But I haven't performed it yet. It sort of doesn't matter whether it's a good piece or not. In the course of writing it, I know that I grew immensely."7

Given this strong indication and the frequent primacy of the composer's intentions in the classical music world, it is frankly amazing that anyone interpreted the work in other than a biographical or historical light. However, The Wound-Dresser was quickly swept up in the public discourse on AIDS and homosexuality, in which Whitman also promi- 
nently figured as a gay role model. The close identification provoked a heated exchange in the New York Times in 1992. Jamie James wrote a review comparing Ned Rorem's Pilgrim Strangers, based on selections from Whitman's Specimen Days, and Adams' Wound-Dresser, asking, "Why not the joyful Whitman, the sensual Whitman, the idealistic Whitman? Why should these two composers independently turn to the poet's nightmarish images of hideous physical decay and death?" James insists upon a very clear division among the poet's various identities, not observing any joy, sensuality, or even idealism in the good gray poet of the Civil War. Nor does he see anything except hideousness in "The Wound-Dresser."

James answers his own question by suggesting that both composers were independently influenced by what he unnecessarily dubs "evolutionary biology," meaning that they were both responding to the same social issues. However, he parenthetically notes, "Interestingly, it is not Mr. Rorem, a gay composer, but Mr. Adams who dares to emphasize explicitly the poet's homosexuality, and thus implicitly his work's connections with the AIDS epidemic, by concluding with the line 'Many a soldier's kiss dwells on these bearded lips."' James was apparently not conversant with the poem, unless we suppose that he expected that Adams would enforce a different ending to his song, making cuts to the end as he did to the beginning. This unclearness aside, his identity politics were criticized by a livid Rorem, who replied to the Times, "Why are the admittedly similar texts, chosen by myself and Mr. Adams, implicitly connected with the AIDS epidemic (I thought they were about the Civil War), unless Mr. James, at this late date, still holds to the specious notion of AIDS as a homosexual disease? Even at that, what has AIDS to do with Whitman?" He also took offense to being identified as gay while Adams is not identified as straight. Instead, Adams is merely assumed to be so, thus normalizing heterosexuality. ${ }^{9}$

Rorem might also have been displeased that James called his song overly pretty, upholding Adams' as by far the superior of the two. Regardless of other motivations, Rorem justly points out the leap that was made by James and perhaps also by other contemporaneous reviewers, using Whitman's sexuality to create or strengthen the links between Whitman's Civil War dresser and the carers of the AIDS epidemic. Nowhere in his article does James make the link between the Civil War and the AIDS epidemic based on nursing and caretaking. Rorem explicitly asks whether the AIDS epidemic was only linked to Whitman's war days by virtue of its public identification with homosexuality, and implicitly asks whether the poem would be so interpreted if Whitman had been heterosexual. The identity politics, as he notes, bleed over from Whitman himself to the composers and James' polarized interpretation. 
Classical reviewers have as divided a view on Adams' treatment of the poem's homoerotic possibilities as on its musical merits. Whether the restraint of the piece was ennobling or stultifying was, in sensuality as in musicality, a polarizing issue. There are differences among performances, of course, with one reviewer singling out the 2004 recording by baritone Nathan Gunn and conductor Marin Alsop as bringing the "homoaffective subtext" to the fore. Times reviewer Alex Ross hails the piece's "cool sensuality." Andrew Stiller, on the other hand, critiques the piece as being too "respectable" musically, adding, "[T]he poet bears 'deep in my breast a fire, a burning flame' that is nowhere addressed by the music (save in one high trumpet note) and neither is the poem's barely disguised homoerotic subtext." He concludes that the piece is "bland" and "pleasant" but "nothing more." Once again, it is Whitman's feelings and emotions that must be prioritized-perhaps not an unreasonable request for a song-setting, but still an instance of extremely scrupulous concern for his authority. The homoerotic or homoaffective subtext is treated as a given, not analyzed textually, biographically or historically, showing how widespread the identification of Whitman as a gay poet is in some circles (despite the ongoing public battles). ${ }^{10}$

When The Wound-Dresser premiered, it was the first reviewer, Michael Fleming, who wrote, “To many listeners, Whitman's account of tending soldiers wounded in the Civil War will seem to pre-echo the task of those who care for AIDS victims today. Adams does not deny this resonance, but says that the work is less specific, applicable to all who in any age tend the suffering." This is the first mention that I can find of the song in the AIDS epidemic context, and it is important to note that Fleming presents it as his own 'resonance,' rather than Adams'. Adams started to speak to this issue more, though still obliquely (perhaps in response to a question), as he promoted the piece later in the year, saying to the New York Times, "There's no denying the fact that people are very caught up in the problem of compassion these days-not just AIDS, but dealing with all the downtrodden and helpless in our society." In seeking to escape (or add to) this particular categorization of Whitman's poem, Adams slips from his primary Civil War context to an extremely broad universalism. A profile on the baritone Sanford Sylvan also implicitly linked his homosexuality to his attachment to The Wound-Dresser, though Sylvan demurred at imposing such a framework, saying, "In San Francisco the piece has different connotations than it does for listeners in Japan. . . . Still, it leaves an indelible impression. I've seen 'The Wound-Dresser' tear up audiences everywhere."11

Adams' quiet attempt to link Whitman to all carers, rather than specifically the AIDS carers, and Sylvan's seeming agreement with him, make the same move as Rorem's letter, attempting to shift the initial 
attention away from Whitman's sexuality; Adams once characterized the relationship between carer and patient as non-romantic and even non-corporeal. ${ }^{12}$ Still, Adams' recent joking with Gilbert about sex being in the poem as well as suffering and dying indicates a comfort with these blended layers of the song that his 2008 memoir, Hallelujah function, specifically supports. Adams even refers to the AIDS epidemic as part of his own original inspiration, writing:

In a Berkeley bookstore I'd found an edition of the Whitman book that included graphic and disturbing photographs of Confederate and Union field hospitals, wounded soldiers, and the long rows of cots filled with the broken bodies of young men lying in stunned stillness. These images, along with the gentle homoeroticism of Whitman's texts, made me think of the stories I heard from San Francisco friends, many of them gay, who had lost partners and loved ones to the plague of AIDS that, in 1989, was still devastating the country.

As I began to work seriously with the Whitman texts I found myself plunged into the memory of a more personal story, that of the long, slow decline of my father from Alzheimer's disease. ${ }^{13}$

Adams' shift from Whitman's time period to his own contemporary and personal experiences is, as Rorem might protest, bridged neatly by the reference to Whitman's homoeroticism (at least as evinced in his poetry), without which the jump from the Civil War to San Francisco only happens through images of mass death. But by invoking the great suffering of the field hospitals, the historical importance of the Civil War, and Whitman's "gentle homoeroticism" in a heroic military context, Adams also uplifts the AIDS epidemic, lest any of his readers have negative associations with homosexuality or the disease. He continues by writing at some length about his mother's struggles to care for his father, thus emphasizing the biographical. Adams unites his compelling but gently generalized images of nursing and loss during both the Civil War and AIDS epidemic with the highly personal, suggesting, in effect, that his audience do the same. (Whether Rorem would do so, given his strict invocation of the Civil War, is unclear.)

Instead of a struggle against the poem's applicability, the knowledge of history forms a road to understanding that the poem can work on several different levels, the most personal being the most important. Adams expressed this concept in a talkback in 2010, strongly emphasizing the poem's Civil War context and bringing it back to his own life. He said, "What spawned the idea of Wound-Dresser was actually a book of pictures. There was a book of pictures by Matthew Brady of these hospital tents. And I looked at them and tried to imagine ... I have a son. . . . As a father you can't not imagine what it would be like to have an 18-year-old boy and have him go off to war ... and the loneliness and desperation of being a wounded soldier and never knowing if you're going to see anyone 
again," thus bringing in the image of contemporary soldiers. He added later, "It went way beyond the Civil War. It was about caregiving, I wrote it in the time of the AIDS plague." Returning to the AIDS epidemic and admitting its importance as historical background secondary to the Civil War, Adams offers Whitman as a poet whose understanding of America can speak to contemporary problems and our own "act of taking care of somebody," whatever and whenever that might be. ${ }^{14}$

Whitman's persona thus grows and expands as Adams' discussion moves away from the Civil War to the modern context. Adams said, at this same event, "I think [Whitman] would be thrilled to see how America is becoming multicultural. But he would also see in all the dark toxic things that are going on right now, the mendacity and this phrase 'take back my country,' that kind of thing, he would also see . . . you know, the Civil War was a very bitter kind of time." Relating Whitman's politics to the current political situation, Adams looks beyond the issue of war-except as a metaphor, perhaps a "life on the march" to mirror the anonymous 1865 critic. Quite early in The Wound-Dresser's life, Adams expanded the scope of its social commentary even further, saying, "We've truly lost sight of models like [Whitman's caring] in our time. Young people today have been shown other models which have to do with aggression and material well-being." 15

The widening of the meaning of Whitman's poem and Whitman as cultural icon to larger fields of human suffering is hardly unique to Adams or to the consideration of Adams' song. The supposed "allcomprehending vision" of Drum-Taps implies an all-comprehending applicability against which Adams himself has only sometimes contended. An early Times article referred to the "universal significance" of suffering, taking the reader quickly from the Civil War to Adams' family to AIDS carers and, in Adams' own words, all the downtrodden and helpless. In comparison, the Washington, D.C. Metro dedicated an AIDS/HIV Memorial at the Dupont Circle station in 2007 which featured several lines from the last verse of "The Wound-Dresser" carved into stone. Some board members, in a move reminiscent of Adams' words about all who tend the suffering, asked for it to be dedicated generally for all who suffer through devastating illnesses, but it was, as originally intended, dedicated specifically to the AIDS/HIV epidemic. This association had, by 2007 , completely fallen out of discussions of the song; in this case of the memorial, there were no quibbles about the poem's applicability or, as far as I could learn, any mention of Whitman's own experiences or sexuality, with the poem treated as an entirely separate object. The poem's last two lines about the soldier's kiss were not included, which certainly might indicate some sensitivity about the topic of homosexuality, as might the board members' initial request. Overall, however, it was a memorial curiously devoid of large discussion or controversy. Nor was 
the poem's Civil War context publicly addressed, which in turn precluded any mention of the current wars and their casualties, the more so since the memorial was directed at illness rather than injury. ${ }^{16}$

In spite of his projection into Whitman's feelings about contemporary issues, Adams does not address the elephant in the room-the contemporary war with which the audience today might as readily identify as the 1990s audience did with the AIDS epidemic. (A brief possible allusion is the aforementioned one of his own son going off to war, which would presumably be the modern wars in the Middle East.) Though Adams ultimately brings his own interpretation of "The Wound-Dresser" out of the Civil War and into modern social commentary, he passes over the specific relation to modern war as he earlier sought to elude the identification with the AIDS epidemic.

In this, Rorem claims a link with Whitman which Adams has not. In his angry Times response, Rorem disclaimed James's identification of him as a gay composer writing about gay Whitman, saying instead, "I wrote it not because I am gay but because I am a pacifist, and because the words, as we Quakers say, spoke to my condition."17 Pacifism is the central battleground upon which reception of The Wound-Dresser in the 2000 s has been fought. Adams himself sets up a dual (perhaps treble) framework through which to interpret this song: its Civil War context and a larger ideal of compassion and caregiving. He specifies, however, that the poem (and by extension, one would presume, his song) is far from "fervently anti-war. . . Whitman hated war-this particular war and all wars-but he was no pacifist. Like his idol, Lincoln, he never ceased to believe in the Union's cause and in the dreadful necessity of victory." But then, as if to cover his bases, he then goes on to say: "The Wound-Dresser is not just about the Civil War; nor is it just about young men dying (although it is locally about both). It strikes me as a statement about human compassion of the kind that is acted out on a daily basis, quietly and unobtrusively and unselfishly and unfailingly.” Adams and Rorem are thus in direct opposition on this subject, though Rorem may be identifying with certain of Whitman's words rather than labeling Whitman a pacifist as well. ${ }^{18}$

In the above statement, which appeared in his 1988 score notes and have been repeatedly reprinted, Adams seeks to simultaneously ground and unground Whitman's poem historically. He insists on Whitman's non-pacifist nature, giving a specific historical comparison to Lincoln and the Civil War's righteous cause that, we must recall, does not appear in the poem. But then he dismisses this as a "local" meaning and creates, once again, a universalized human compassion; the war itself is both essential and peculiarly irrelevant to his interpretation, as if any large-scale death and disaster would have inspired the same set of con- 
cerns in Whitman. Once again, he prefers an extremely general modern application to a specific one.

Adams' demureness does not represent any affectation of an apolitical rarefied aesthetics, however. Some of Adams' most famous works are his politically themed ones, such as the opera Nixon in China and the choral work "On the Transmigration of Souls," composed in commemoration of the $9 / 11$ victims. He is certainly far from demure about the importance of current political situations to his work, nor is he a stranger to controversy. The Death of Klinghoffer, his opera about the 1985 hijacking of the Achille Lauro, evoked an outcry at its 1991 premiere because it was perceived as overly favorable to the Palestinian hijackers, and has repeatedly done so since then, particularly after the events of September 11, 2001. This being the case, it is unsurprising that performances of The Wound-Dresser have continually made reference to the modern wars, sometimes if only to disclaim them.

In the last several years, there have been several major performances of The Wound-Dresser, impelled by musical trends and its implicit topicality. With the AIDS epidemic gone from front pages and the front of mainstream public consciousness, performances of The Wound-Dresser have been shadowed by more war, this time the wars in Iraq and Afghanistan and the general 'war on terror.' "Poetry for a Time of Calamity and War" headed a review of a 2010 performance; "Music for a Time of War," proclaimed the Oregon Symphony in a 2011 concert. These titles, however, were not often followed by any open discussion of the current war, which created an odd atmosphere in which the debate about Whitman's intentions and pacifism was charged with urgency, but brought to no conclusion.

An exception occurred when the Chicago Symphony Orchestra and Nathan Gunn performed The Wound-Dresser at a large open-air concert in Chicago's Grant Park in August 2007 called, punningly but meaningfully, "Grant Us Peace" and dedicated to members of the U.S. military. This name led to a feature article in popular TimeOut magazine that heavily focused on the war and made much of Gunn's family history (his grandfather fought at the Battle of Okinawa during World War II). "[D] on't mistake a 'Grant Us Peace' concert for an anti-war platform," wrote the author. He takes his tone from Gunn, who said when interviewed, "War is a reality and it is, in the truest sense of the word, a pity. ... This is what I think gives power to the music and the text. War for this poet is like a civilized crime. What I mean is that if we want civilization, there will be war. These sorts of themes really inspire me and honor the soldiers that they describe." As the article was a profile of Gunn, rather than a discussion of the work or politics, the author was able to frame this issue around Gunn's musical inspiration rather than probing the paradox of a "civilized crime." The question of Whitman's 
anti-war politics was crucial to address, however, in the wake of anti-war protests in Chicago in the preceding few years (as in other large American cities at this time), some of which were located in Grant Park. Gunn's tone of support for the troops appeared to be the guiding principle for the concert's reception; one review suggested that it explored "[a] sense of personal connection to wartime sorrow," once again invoking the personal identification with a larger historical or at least very unspecific context rather than addressing the ongoing war openly. ${ }^{19}$

The pattern of addressing the issue but backing away from a political stance was repeated elsewhere. In the same year as the CSO's Grant Park concert, the program notes for a Baltimore Symphony Orchestra concert at which the Wound-Dresser was performed by its original interpreter, Sanford Sylvan, begin: “Composed in 1988, Adams' The Wound-Dresser may seem even more meaningful to those listening to it in 2007, with the horrible human toll of the Iraq War assaulting us every day as well as the recent troubling revelations about conditions at Walter Reed Hospital." However, the notes then abruptly turn away from any such meaning, assuring the audience members that Adams actually had the personal tragedy of his father's death in mind, and reprinting Adams' original score notes (with the historical grounding and ungrounding) in full. At one of the BSO concerts, Adams did say of the piece, "Unfortunately, a very timely poem," but little more, leaving the modern associations to the imagination. ${ }^{20}$

The reception of specific moments in the song reflects some of the unease with immediate applicability. American bass-baritone Eric Owens said that people in the audience are visibly affected by the line about youth ("some are so young, some suffer so much"), something which both he and Gunn relate to the youth of our current soldiers. Gunn, when asked what the most difficult or affecting line was, opted for "Cleanse the one with a gnawing and putrid gangrene, so sickening, so offensive." He elaborated on this choice, writing that this section is "so vivid that it can turn people away if not handled and expressed in a way that also expresses the action that is going on at the moment the words are written; he is caring for these poor, dying men. This, I think, is the most difficult part of the piece, finding a way to describe the horror of the situation without expressing disgust." These are the two lines that are most mentioned by reviewers - the unnerving image of the gangrene draws significant attention, emphasized musically as well. ${ }^{21}$ But here, as elsewhere, it may be easier to look at (to borrow Adams' terminology) the local; the gangrenous wound is easier to dehumanize and historicize than the young soldier entire, who forces personal associations. As with Adams' reference to his own son, both Gunn and Owens see the tie between the young soldiers of Whitman's time and our time as the empathetic foundation upon which these "music for a time of war" programs can build, bringing the personal identification to the forefront once again. 
When the New York Philharmonic, under the direction of Alan Gilbert and with artist-in-residence Thomas Hampson, took The WoundDresser on tour in Europe in the 2009-10 season, they also sidestepped its seemingly obvious political commentary. The program notes offered a focused analysis of John Adams' oeuvre as well as his own original score notes (showing Adams' own dominance over the interpretation of his work). Hampson said publicly, "It is NOT an anti-war statement. It is NOT a political diatribe. This is the most important part for me of this piece going on tour to Europe. This isn't about America going over and saying look, we have anti-war poetry. This isn't anti-war poetry. This is human compassion poetry." I was not able to learn whether this was in response to specific queries from the public or concerns on the part of the Philharmonic, but Hampson, in his public lectures for the Philharmonic in New York, stressed-as he has done in other interviews-over and over that this poem and song are not anti-war, showing an awareness of how it is interpreted by others. Gunn alluded to a similar sense that this is the case, writing, "It surprises me that most people think this poem is an 'anti-war' statement." 22

Even the Oregon Symphony's rather explicitly named "Music for a Time of War" program passed over the current state of affairs, focusing on the historical contexts of all of the chosen pieces and, yet again, making much of Adams' story about his parents. In contrast to these classical music pronouncements of the last decade, a 2000 review of a Boston Ballet performance that used the "Wound-Dresser" poem as inspiration for its choreography made no bones about referring to the poem as "Whitman's war protest," though as we might by now expect, also extrapolated its meaning to "death's effect on a larger scale." 23

Reviews of the Music for a Time of War program, as released on CD in 2011, dwell on pacifism, showing that for all the rejection of potentially anti-war politics in The Wound-Dresser, its possible pacifism is never far behind. "One might assume that Music for a Time of War has a pacifist agenda ... [but] the liner notes were silent on the issue of pacifism," wrote Andrew Quint, who suggests that perhaps the music addresses the impossibility of understanding motivation. Because composer Benjamin Britten, also included in this program and Gunn's Grant Park program, was a well-known pacifist, the associations bleed over, infringing upon Whitman's and Adams' authority. Overwhelmingly, reviews (and the liner notes) mentioned Britten's pacifism. Reviewer Michael Miller did so, but he also went further than any other reviewer, critic, or performer in denying the war connections of The Wound-Dresser, relying on Adams' characterization of the song as "more about caring for the sick and suffering" and completely eschewing Whitman's "experience as a nurse in the Civil War." Indeed, he went so far as to say that the Britten piece was the only one "entirely and explicitly about war" on the CD. The 
liner notes of the CD may have prompted him in this direction, as they quoted Adams' original dehistoricizing score notes, "It strikes me as a statement about human compassion of the kind that is acted out on a daily basis, quietly and unobtrusively and unselfishly and unfailingly," with a quick mention of Whitman's Civil War nursing. The notes do offer an interesting critique or backhanded praise of American national temperament, "seldom dwelling on misery [of war and tragedy] to the point of total despair," suggesting that the song's "golden-voiced beauty" can erase the "grim and grey" thoughts. But if the song itself can erase thoughts of war, it is certainly not pacifist; it is comfort music, perhaps the one thread that had not appeared in discussion or review until 2011. ${ }^{24}$

The obvious link between Whitman's possible pacifist politicswhich have been debated at length in literary studies - and the opposition to the modern war has not precluded the discussion of the song's Civil War context. Some concert programs have reprinted Adams' original score notes in full. Among the artists, Hampson is veritably steeped in Whitman studies and the history of the time period, which he has also displayed in his public lectures. Gunn, too, read "various other writings about the Civil War," and Adams' blog post on the New York Philharmonic's 2009-2010 performances, written after watching a rehearsal, reflects exclusively on the Civil War, recommending historian Drew Gilpin Faust's This Republic of Suffering to his readers. ${ }^{25}$ The discussion of the historical setting is thorough and complete, far more so than the tentative references to the modern wars.

Judging from the singers' own interviews, the modern interpretation of the piece appears to have cohered to ideals of caregiving to soldiers, leaving behind the generalization of caregiving and compassion during the AIDS epidemic context. Sylvan, the most enduring interpreter, reflected on the ebbing of that context: "It was terrifying and thrilling and impossible to sing it for people who knew every day of their lives what that was." But, he continues, "I think the piece now is more about itself." What exactly that might mean, of course, is another question. Hampson, speaking firmly from a general context, said, "It's about compassion. It is a kind of reflection of human need and human misery and aggression, met with living compassion." Notably, however, he tends to speak of the poem's content as caretaking in the time of an actual military war or "aggression," rather than, say, AIDS or other illness. Interestingly, Owens, who has performed the work twice, once at the BBC Proms in 2006, certainly a lively time in the discussion of war, and once in Washington, D.C. with Adams in 2010, told me in a phone interview that he had never before been asked the war/anti-war question. (Owens was present at the talkback with Adams mentioned previously, in which Adams suggested Whitman's probable thoughts about contemporary society but was never asked openly about war.) He reflected on the subject: "I haven't really 
said to myself this is an anti-war piece; I think it's more of celebrating the individuals who tend to these wounded people and . . how, if we are going to have wars, that it's important that the young men who are fighting those wars are looked after when they're fallen and injured and need the best of care." While he did not strongly opine on the question of war vs. anti-war, Owens clearly interprets the piece more in the context of care. He gave an interesting reason why this might be a preferable interpretation, pointing out, "The energy is always higher when you're for something rather than being against something." Gunn opined, "I personally feel that the piece is (much like Britten's War Requiem) more a statement about the pity of war and an honest description of the reality of war which is that soldiers die." Why, however, the AIDS epidemic was accepted as a strongly related context while the debate of the song's pro- or anti-war politics continues to be so vexed, is baffling; perhaps we can attribute it to the volatility of the current political situation or the lack of a strongly embraced personal identification by Adams or another artist. The ambiguity of Whitman's politics appears not to be a sufficient anchor. Perhaps, in future years, Adams may speak more comfortably and openly about the relation to the wars in Iraq and Afghanistan, as he gradually did about AIDS/HIV. ${ }^{26}$

In a relatively short time, marked by a manageable number of recordings and performances, it is astonishing how many different currents Adams' Wound-Dresser has tapped into, both in the discourse about Whitman's identity that arises in the public sphere-the gay poet, the good gray poet-and the Whitman studies that inform them. The song serves as the perfect test case for these identities, as it has endured two different 'wars,' and both the war on AIDS and the wars in Iraq and Afghanistan spoke to the historical polar opposites of Whitman's public identities. If there is a constant among the views surveyed here, it is the hope that the audience will find a deep personal connection with some aspect of the song, as suggested by Adams' multilayered invocation of Civil War history, more recent social context, and his own family story. While Whitman's overshadowing authority might initially seem restrictive, his multiplicitous identity might actually enable this freer interpretation. The public perception of Whitman has slowly grown to be more complex, recognizing that good grayness and gayness are far from incompatible, as The Wound-Dresser dramatically underscores. But the wildly changing reception of the song shows that the debates over his politics, as well as the larger literary debates about historical particularity and universality, are still profoundly difficult to frame. 


\section{NOTES}

My especial thanks to Nathan Gunn, Eric Owens, and Katie Klenn of the Communications Department at the New York Philharmonic.

1 “Drum Taps. - Walt Whitman,” Watson's Weekly Art fournal (November 4, 1865). Available online on the Walt Whitman Archive (whitmanarchive.org).

2 Walt Whitman, "The Wound-Dresser," in Leaves of Grass, A Textual Variorum of the Printed Poems: 1860-1867 (New York: New York University Press, 2008), 2:479-482. John Adams, "Listening to Walt Whitman," Hell Mouth [blog], January 15, 2010, www. earbox.com (Official website of John Adams). Hereafter, LtWW.

3 Betsy Erkkila, "Introduction: Breaking Bounds," in Breaking Bounds: Whitman and American Cultural Studies, ed. Betsy Erkkila and Jay Grossman (New York: Oxford University Press, 1996), 8, 9.

4 Lawrence Buell, "American Civil War Poetry and the Meaning of Literary Commodification: Whitman, Melville, and Others," in Reciprocal Influences: Literary Production, Distribution, and Consumption in America, ed. Steven Fink and Susan S. Williams (Columbus: Ohio State University Press, 1999), 130.

5 J. M., Review of The Wound-Dresser, Gramophone (June 1990), 90 [hereafter, Gramophone Review]; Kyle Gann, "A Composer, Not a Minimalist: To Groove or Not to Groove," The Village Voice (September 21, 1999), 114. Daniel Felsenfeld, Liner Notes, Shaker Loops/The Wound-Dresser/Short Ride in a Fast Machine, CD, Naxos, 2004.

6 Gerald S. Fox, Review of Collections: Cleveland Orchestra/Christoph Von Dohnanyi, American Record Guide 65 (May-June 2002), 179. J.M., Gramophone Review. For performance critiques, see, for example, Michael Fleming, 'Adams Shines with 'Nixon,' 'Wound-Dresser'," St. Paul Pioneer Press (February 26, 1989) [hereafter, "Adams Shines."]; and Anthony Tommasini, "New York Philharmonic: Poetry for Times of Calamity and War," New York Times (January 16, 2010).

7 John Adams, "Note by the Composer," in The Wound-Dresser (New York: Boosey \& Hawkes, 1989). Adams, LtWW. James Chute, "Both Humor and Heft Give Symmetry to John Adams' Music," The Orange County Register (February 14, 1989), F01.

8 Jamie James, "Recordings View: Two Americans Converge on Whitman", New York Times (March 1, 1992). Hereafter, "Recordings View."

9 James, "Recordings View." Ned Rorem, "Whitman to Music: Critical of Critique," New York Times (March 15, 1992). Hereafter, "Whitman to Music."

10 Raymond Tuttle, "Classical Recordings," Fanfare (March-April 2005), 80; Alex Ross, "How Ever Did You Do It, Mr. Ives?," New York Times (November 15, 1994); Andrew Stiller, "Review of Adams: Fearful Symmetries, The Wound-Dresser (Elektra/ Nonesuch CD)," Musical America (September 1990), 73.

11 Fleming, "Adams Shines"; K. Robert Schwarz, "The Two Sides of One Man's Music," New York Times (November 26, 1989), [hereafter, “The Two Sides of One Man's Music"]; Allan Ulrich, "Master singer: Baritone Sanford Sylvan talks about American music, his life partner, and singing in Carmel," The Advocate (July 21, 1998), 65.

12 Schwarz, "The Two Sides of One Man's Music."

13 John Adams, Hallelujah function: Composing an American Life (New York: Farrar, Straus and Giroux, 2008), 150. 
14 John Adams, Talkback with John Adams and Eric Owens, Kennedy Center for the Performing Arts, Washington, D.C., May 13, 2010. Video available at www.kennedycenter.org. Hereafter, Talkback.

15 Adams, Talkback. J. M., Gramophone Review.

16 Schwarz, "The Two Sides of One Man's Music." Washington Metropolitan Area Transit Authority, "Dupont Circle Metrorail Station Artwork Proposal," WMATA (June 25, 2011); "Metro Approves New Art Project at Dupont Circle," Press release, Feb 17, 2006, WMATA, June 25, 2011, available at www.wmata.com.

17 Rorem, "Whitman to Music."

18 Adams, "Note by the Composer."

19 Bryant Manning, "Straight Shooter," TimeOut Chicago (August 16-22, 2006), 120. Wynne Delacoma, "Grant Park Fest Closes Summer with Dark Honors," Chicago Sun-Times (August 20, 2007), 43.

20 Programming notes, My Father Knew Charles Ives and The Wound-Dresser, Baltimore Symphony Orchestra (October 4-6, 2007), available at www.bsomusic.org; Tim Smith, "Adams Conducts, Invigorates Concert," The Baltimore Sun (October 6, 2007), 5D.

21 Eric Owens, Telephone Interview (September 29, 2010), [hereafter, Telephone Interview]; Nathan Gunn, "Wound-Dresser Questions," Email to the author (September 1, 2010) [hereafter, "Wound-Dresser Questions"]. Gunn did not work with Adams on this particular piece, though he did pay close attention to the score and Adams' notes there, in particular one Whitman quote: "Those who love each other shall become invincible." The singling out of the gangrene image appears in, for example: Sarah Cahill, Liner Notes, Fearful Symmetries/the Wound-Dresser, CD, Nonesuch, 1989; Philip Clark, "John Adams - the Wound-Dresser," Program Notes, BBC Four Proms, London (August 11, 2006); Mark J. Estren, "John Adams, Conducting Himself Admirably," The Washington Post (October 6, 2007), C5.

22 Thomas Hampson, "Listening to Thought: Awakening of the American Voice," Erich Leinsdorf Lecture, New York Philharmonic, New York City (January 11, 2010). See also "International Performances of John Adams's The Wound Dresser with the New York Philharmonic," Press release (January 10, 2010), www.thomashampson. com [hereafter, "International Performances"]; Gunn, "Wound-Dresser Questions."

23 Elizabeth Schwartz, "Music for a Time of War," Program Notes, Oregon Symphony, Portland, OR (May 7-8, 2011), available at www.orsymphony.org; Anna Kisselgoff, "Dance Review; in Boston, a Reassertion of Strength Amid Change," New York Times (October 10, 2000).

24 Andrew Quint, "Oregon Symphony CD Review," The Absolute Sound (March 2012). Reprinted and accessed at Oregon Symphony official website. Michael Miller, “'Music for a Time of War'-The Oregon Symphony under Carlos Kalmar plays Ives, Adams, Britten, and Vaughan Williams on a Pentatone Release...Highly Recommended!" The Berkshire Review (April 7, 2012); Steven Kruger, Liner Notes, Music for a Time of War (Oregon Symphony/Carlos Kalmar), CD, PentaTone (2011).

25 Gunn, "Wound-Dresser Questions.” Adams, LtWW.

26 Zachary Woolfe, "Classical Music's Prodigal Son: Sanford Sylvan Returns to New York," New York Observer (May 17, 2011). Hampson, "International Performances." Owens, Telephone Interview; Gunn, "Wound-Dresser Questions." 